\section{Determinants of early cognitive development: hierarchical analysis of a longitudinal study}

\author{
Determinantes do desenvolvimento cognitivo \\ na primeira infância: análise hierarquizada \\ de um estudo longitudinal
}

\author{
I Instituto de Saúde Coletiva, \\ Universidade Federal da \\ Bahia, Salvador, Brasil. \\ 2 Escola de Nutrição, \\ Universidade Federal da \\ Bahia, Salvador, Brasil. \\ Correspondence \\ L. M. Santos \\ Instituto de Saúde Coletiva, \\ Universidade Federal da \\ Bahia. \\ Rua Basílio da Gama $s / n$, \\ Campus Universitário \\ Canela, Salvador, $B A$ \\ 40110-040, Brasil. \\ marquesleticia@hotmail.com
}

\begin{abstract}
The study describes the relationship between anthropometric status, socioeconomic conditions, and quality of home environment and child cognitive development in 320 children from 20 to 42 months of age, randomly selected from 20,000 households that represent the range of socioeconomic and environmental conditions in Salvador, Bahia, Northeast Brazil. The inclusion criterion was to be less than 42 months of age between January and July 1999. Child cognitive development was assessed using the Bayley Scales for Infant Development, and the Home Observation for Measurement of the Environment Inventory (HOME) was applied to assess quality of home environment. Anthropometric status was measured using the indicators weight/age and height/ age ratios (z-scores), and socioeconomic data were collected through a standard questionnaire. Statistical analysis was conducted through univariate and hierarchical linear regression. Socioeconomic factors were found to have an indirect impact on early cognitive development mediated by the child's proximal environment factors, such as appropriate play materials and games available and school attendance. No independent association was seen between nutritional status and early cognitive development.
\end{abstract}

Child Development; Preschool Child; Nutritional Status
Letícia Marques dos Santos 1

Darci Neves dos Santos 1

Ana Cecília Sousa Bastos 1

Ana Marlúcia Oliveira Assis 2

Matildes Silva Prado 1

Mauricio L. Barreto 1

\section{Introduction}

Early cognitive development is associated with the development of memory and social skills, language acquisition, logical reasoning, planning, and problem solving 1 . These aspects interact in an organized way, producing developmental results that change according to environmental and personal factors that mold and determine the rhythm and direction of cognitive development. The first years of life constitute a critical period of rapid personal change, and the events of this phase prepare the child for subsequent developmental competency 2,3.

Recent research investigating how different environments either facilitate or hinder child development has mostly focused on social environment. The impact of social environment has been divided into two levels: a distal one, related to the social, historical, and cultural context of children's lives, and a proximal one, related to children's immediate physical and social environment, comprising their daily interactions with family, peers, teachers, and significant others. Given the above, it is assumed that distal risk factors do not directly affect the individual, but are mediated by factors from the proximal environment, such as verbal stimulation, quality of childcare, and family organization, including adult-child interaction and emotional involvement $4,5,6,7,8$. 
The interactions that occur between the child and people, objects, and symbols in the child's immediate environment constitute the proximal processes that propel human development. To be effective, these processes need to occur regularly for long periods of time while becoming more extensive and complex. These proximal processes vary systematically according to personal and contextual characteristics and the historical period in which the person was involved 9 .

A recent literature review of factors affecting child cognitive development showed the association of several conditions related to nutritional deficiencies, making it difficult to determine a direct correlation between malnutrition and cognitive development. Many risk factors associated with both malnutrition and cognitive development derive from the distal level, such as socioeconomic conditions and access to health services, and their mechanisms acting on the developmental outcome are still not fully understood 7,10,11,12,13.

Several authors have formulated hypotheses to explain the mechanisms by which malnutrition affects cognition $14,15,16,17,18$. The most widely accepted assumption considers the effects of malnutrition as a result of a complex process of behavioral, social, and environmental deprivation. Material needs as well as psychosocial resources, such as maternal schooling, are likely to interact and affect children's behavioral outcome 16 . Mendez \& Adair 19 claim that since malnutrition often occurs in an environment of multiple psychosocial disadvantages, the availability of educational and economic resources should be considered while exploring an independent association between malnutrition and cognitive development.

The present study aimed at identifying determinants of cognitive development in children from 20 and 42 months of age living in Salvador, Bahia State, Brazil. More specifically, the study was intended to describe the impact of anthropometric status on child cognitive development, controlling for socioeconomic status and quality of home environment, which are considered factors from the distal and proximal environments, respectively.

\section{Materials and methods}

The study reported here had a cross-sectional design integrating a longitudinal study, started in 1997, aimed to investigate risk factors for diarrhea in a sample of 1,153 children 20 . Children younger than 42 months during the first six months of 1999 were eligible to participate in the cognitive study sub-sample.

\section{Sampling}

For the initial study, a set of 30 "sentinel areas" containing approximately 20,000 households were selected to represent the range of socioeconomic and environmental conditions in the city of Salvador 20. A cohort of 1,153 children under 3 years at baseline was randomly selected from these households, and 510 children in this population were younger than 42 months before June 1999. Of these, 320 families agreed to participate in this study, completing data on domestic psychosocial stimulation and cognitive function. There were no statistically significant differences between subjects and 190 losses concerning the anthropometric indicator weight/height ratio ( $p=0.65$ ), proportion of mothers with less than four years of schooling ( $\mathrm{p}=0.72)$, and quality of external home environment $(p=0.09)$.

\section{Study instruments}

\section{- Cognitive development}

The Bayley Scales for Infant Development: Second Edition 21, a widely recognized, reliable, and valid standard instrument was used for assessing mental and motor development in children 1 to 42 months of age. These scales are composed of 3 independent and complementary sub-scales: mental, motor, and behavioral. In the present work, the mental scale index was used as an indicator of cognitive development, because this scale includes items that evaluate memory, habituation, problem solving, primary numeric concepts, generalization, classification, vocalization, language, and social strategy.

These scales are widely applied in research aimed at determining individual and group differences, defining developmental risk groups and planning interventions. Latin American studies have employed these scales to identify risk factors for child development 22,23. In Brazil, the Bayley scales have been used to evaluate developmental differences between healthy versus low birth weight or premature newborns 24,25,26.

\section{- Quality of home environment}

The Home Observation for Measurement of the Environment (HOME) inventory, an instrument developed and validated by Caldwell \& Bradley 27 , was used to assess quality of home environment. The HOME inventory has been widely applied in different social and cultural backgrounds to as- 
sess quality of home environment and its impact on cognitive and emotional development during the first five years of life. It describes emotional and verbal maternal responsivity, avoidance of restriction and punishment, organization of the physical and temporal environment, provision of appropriate play materials and games, maternal involvement with the child, and opportunities for variety in daily stimulation.

\section{- Anthropometric status}

Weight and length/height were measured in 1998. Children's weight was measured using $100 \mathrm{~g}$ precision electronic scales; a stadiometer was used for measuring the height of children older than 2 years old and a wooden infantometer was used for those younger than 2 years old. Anthropometric status was assessed using the indicators height/age ratio and weight/age ratio (z-score) according to the National Center for Health Statistics standards 28 .

\section{- Socioeconomic status}

A pre-coded sociodemographic questionnaire was administered to caretakers in 1997 to assess the family's socioeconomic conditions. Information on maternal schooling, family income, internal and external home environment, and family structure was collected.

\section{Data collection and analysis}

The Bayley scales and HOME inventory were administered between January and July 1999 when children were assessed at home by a team of four psychologists and four supervised psychology students. This team was trained by a qualified professional, and the students were constantly and directly supervised by a specialist in infant evaluation.

An analysis for HOME inventory data showed an intra-examiner agreement of $87.46 \%$ (SD = 7.49). For the Bayley scales, training procedures were performed in strict agreement with the Bayley manual instructions, thereby minimizing error between examiners.

After coding, data were double-entered into Epi Info version 6 (Centers for Disease Control and Prevention, Atlanta, USA) by two different people. The database was then converted into SPSS software program version 11.0 (SPSS Inc., Chicago, USA) and cleaned and corrected for analysis.

\section{Definition of variables}

To assess the relative relevance of independent variables, several determinants of cognitive development scores were hierarchically arranged in blocks, defined after a literature review, to understand how each hierarchical level might significantly affect early cognitive development scores. The study's theoretical model consists of four hierarchical levels as follows: (1) socioeconomic status; (2) environment; (3) proximal processes; and (4) individual processes. The variables making up each block are described in Figure 1 and were obtained using the study instruments.

\section{Statistical analysis}

First, descriptive analyses were conducted to describe children's level of cognitive development, socioeconomic status, quality of home environment, and nutritional status. The study then investigated potential associations between cognitive performance and its possible determinants through univariate linear regression analysis at $5 \%$ significance level.

Statistically significant associations were studied in a hierarchical linear regression model. To avoid excluding potential confounders, a $10 \%$ significance level was set when including variables in the hierarchical model and a 5\% significance level when maintaining variables in the model.

Outliers were identified and excluded for greater accuracy of the estimates in the model. Deviant cases were defined as those whose standard residual value showed absolute values below two.

\section{Ethical issues}

The study was approved by the Research Ethics Committee of the Federal University in Bahia, Professor Edgard Santos University Hospital. Parents or guardians signed an informed consent form after the study's objectives were explained and information confidentiality was assured.

\section{Results}

The mean age of children was 31.72 months (SD = 5.42) and their mean score on Bayley mental sub-scale was $96.84(\mathrm{SD}=10.14)$. The proximal development environment was described as high-risk for $56.3 \%$ of children according to criteria defined by Zamberlan \& Biasoli-Alves 29 . The mean HOME inventory score was 26.97 (SD = 5.65). Most children (73.4\%) did not attend either 
Figure 1

Hierarchical model for assessing early cognitive development.

Socioeconomic status

- Maternal schooling

Block 1

- Family income

socioeconomic status

- Maternal occupation status

Block 2

Family size and structure

- Home density (persons per room)

- Number of children $<5$ years old

- Quality of external home environment

\section{Organization of child's environment (HOME)}

- Organization of physical and temporal environment

- Provision of appropriate play materials and games

to the child

- Variety in daily stimulation

\section{Individual characteristics}

- Gender

- Age

\section{Child's health status}

- Nutritional status

- Birth weight

- Birth order

- Breastfeeding
Block 3

proximal processes

- Maternal involvement with the child

- Preschool attendance

Cognitive development

Bayley Scales for Infant Development childcare or preschool at the time of the study. The anthropometric indicator revealed mildto-moderate nutritional status $(-3 \leq \mathrm{z}$-scores $<-1$ ) in $20 \%$ of height/age ratio and $24.8 \%$ of weight/age ratio. No severe cases of malnutrition ( $\leq-3 \mathrm{z}$-scores) were found (Table 1 ).

Socioeconomic indicators showed that $26.6 \%$ of the mothers had up to four years of schooling,
$64.7 \%$ were unemployed, and $36.6 \%$ of the families earned up to one monthly minimum wage. In regard to intermediate risk factors, most families $(69.4 \%)$ lived in inadequate conditions (according to the indicator quality of internal home environment) in overcrowded rooms (65.9\%) (Table 2). 
Subjects' characteristics according to children's variables and proximal factors of psychosocial stimulation.

\begin{tabular}{|c|c|c|c|c|}
\hline Variables & $\mathbf{n}$ & Mean & $\begin{array}{l}\text { Standard } \\
\text { deviation }\end{array}$ & $\%$ \\
\hline \multicolumn{5}{|l|}{ Proximal processes block } \\
\hline \multicolumn{5}{|l|}{ Attending school/childcare } \\
\hline Yes & 85 & - & - & 26.6 \\
\hline No & 235 & - & - & 73.4 \\
\hline \multicolumn{5}{|l|}{ Level of risk according to HOME } \\
\hline High & 180 & - & - & 56.3 \\
\hline Low & 140 & - & - & 43.8 \\
\hline Mother's emotional and verbal responsivity & 320 & 7.60 & 1.99 & - \\
\hline Avoidance of restrictions and punishment & 320 & 5.54 & 1.39 & - \\
\hline Organization of the physical and temporal environment & 320 & 3.95 & 1.31 & - \\
\hline Provision of appropriate play materials and games to the child & 320 & 4.87 & 1.99 & - \\
\hline Maternal involvement with the child & 320 & 2.33 & 1.40 & - \\
\hline Opportunity for variety in daily stimulation & 320 & 2.71 & 1.19 & - \\
\hline Total HOME score & 320 & 26.97 & 5.65 & - \\
\hline \multicolumn{5}{|l|}{ Individual processes block } \\
\hline \multicolumn{5}{|l|}{ Gender } \\
\hline Male & 174 & - & - & 64.4 \\
\hline Female & 146 & - & - & 45.6 \\
\hline \multicolumn{5}{|l|}{ Nutritional status (height/age ratio) } \\
\hline Well-nourished & 248 & - & - & 80.0 \\
\hline Malnourished & 62 & - & - & 20.0 \\
\hline \multicolumn{5}{|l|}{ Nutritional status (weight/age ratio) } \\
\hline Well-nourished & 233 & - & - & 75.2 \\
\hline Malnourished & 77 & - & - & 24.8 \\
\hline Age (months) & 320 & 31.72 & 5.42 & - \\
\hline Cognitive development score & 320 & 96.84 & 10.14 & - \\
\hline Birth weight $(g)$ & 316 & $3,164.1$ & 545.10 & - \\
\hline Number of pregnancies & 320 & 2.58 & 2.19 & - \\
\hline Oldest age of breastfeeding (days) & 316 & 85.09 & 91.99 & - \\
\hline
\end{tabular}

HOME: Home Observation for Measurement of the Environment Inventory.

Univariate analysis highlighted the strength of association between maternal schooling ( $\beta=0.353)$, family income ( $\beta=0.317)$, and provision of appropriate materials and games to the child ( $\beta=0.383$ ) and early cognitive development scores. On the other hand, the multivariate analysis showed that the blocks that best reflected the variation in early cognitive development scores were those related to proximal processes $\left(\mathrm{R}^{2} \mathrm{~A}=\right.$ $18.7 \%$ ), which included the variables provision of appropriate materials and games to the child, school attendance, and mother's emotional involvement, followed by the block on socioeconomic status ( $\mathrm{R}^{2} \mathrm{~A}=17.5 \%$ ) (Table 3 ).

In a first step, the hierarchical linear regression analysis included the variables family income and maternal schooling in the model. The latter showed greater strength of association ( $\beta=0.291$ ) with cognitive development scores. Children of mothers who had at least 5 years of schooling and family income of more than two times the monthly minimum wage showed the highest cognitive development scores when compared to those of mothers with lower schooling and family income.

When variables from the environmental block comprising both the physical environment and family size and structure components were included in the model, an increased power of explanation of cognitive development of $3.8 \%$ was seen. Crowding had a negative impact on cognitive development scores $(\beta=-0.150)$, i.e., the more people living in the same dwelling, the lower the child's cognitive development score. Vari- 
Subjects' characteristics according to socioeconomic status, environment, and family variables.

\begin{tabular}{|c|c|c|}
\hline Variables & $\mathrm{n}$ & $\%$ \\
\hline \multicolumn{3}{|c|}{ Socioeconomic status block } \\
\hline \multicolumn{3}{|c|}{ Maternal schooling (years) } \\
\hline$>5$ & 235 & 73.4 \\
\hline$\leq 4$ & 85 & 26.6 \\
\hline \multicolumn{3}{|c|}{ Family income (times minimum wage) } \\
\hline$\leq 1$ & 116 & 36.3 \\
\hline$>2$ & 204 & 63.7 \\
\hline \multicolumn{3}{|c|}{ Maternal occupational status } \\
\hline Employed & 113 & 35.3 \\
\hline Unemployed & 207 & 64.7 \\
\hline \multicolumn{3}{|l|}{ Home environment block } \\
\hline \multicolumn{3}{|c|}{ Quality of external home environment } \\
\hline Moderate to good & 129 & 40.3 \\
\hline Poor & 191 & 59.7 \\
\hline \multicolumn{3}{|c|}{ Quality of internal home environment } \\
\hline Good & 98 & 30.6 \\
\hline Poor to moderate & 222 & 69.4 \\
\hline \multicolumn{3}{|c|}{ Home density (persons per room) } \\
\hline One & 109 & 34.1 \\
\hline More than one & 211 & 65.9 \\
\hline \multicolumn{3}{|c|}{ Number of children $<5$ years old at home } \\
\hline One & 202 & 63.1 \\
\hline 2 to 4 & 118 & 36.9 \\
\hline \multicolumn{3}{|l|}{ Type of family } \\
\hline Nuclear & 178 & 55.6 \\
\hline Extended & 142 & 44.4 \\
\hline
\end{tabular}

ables from the environmental block produced a weaker effect when included in the hierarchical model, suggesting that their effect is partially affected by variables from higher hierarchical levels.

In a third step, variables from the proximal processes block (home environment organization, maternal responsivity, and preschool attendance) were included in the model. Again, an increased power of explanation was seen $\left(\mathrm{R}^{2} \mathrm{~A}=\right.$ $27.5 \%$ ) and the variable provision of appropriate materials and games to the child was the most strongly associated with cognitive development ( $\beta=0.200)$. Hence, the greater the children's stimulation with age-appropriate play materials and school attendance, the higher their cognitive development scores.

It should be highlighted that the variable provision of appropriate play materials and games was the best predictor of cognitive development scores in the univariate analysis $\left(\mathrm{R}^{2} \mathrm{~A}=14.4 \%\right)$ and showed the strongest association $(\beta=0.383$ ).
When it was evaluated together with school attendance and maternal responsivity, the strength of association was maintained ( $\beta=0.302)$. However, the strength of association was only weaker when included in the final model $(\beta=0.200)$, suggesting that the quality of a child's stimulation in the environment is affected by maternal schooling and family income.

Finally, the inclusion of the last block in the analysis revealed that individual variables had a low impact on cognitive development scores, resulting in $0.5 \%$ increased power of explanation. The variable nutritional status proved to have a borderline significance, and when included in the analysis together with variables from higher hierarchical levels it almost failed to affect cognitive development scores $(\beta=0.089$ ).

In the multivariate analysis, the individual processes block had the lowest effect on the explanation of cognitive development $\left(\mathrm{R}^{2} \mathrm{~A}=0.5 \%\right)$. In the hierarchical model, the variables birth order and birth weight lost their statistical signifi- 
Univariate linear regression and hierarchical block multivariate analysis including socioeconomic status, environment, family, and individual predictors of child cognitive development.

\begin{tabular}{|c|c|c|c|c|c|c|c|c|c|}
\hline \multirow[t]{3}{*}{ Components and factors } & \multicolumn{9}{|c|}{ Models } \\
\hline & \multicolumn{3}{|c|}{ Univariate } & \multicolumn{3}{|c|}{ Multivariate } & \multicolumn{3}{|c|}{ Hierarchical } \\
\hline & $\begin{array}{l}R^{2} A \\
(\%)\end{array}$ & $\beta \mathrm{Aj}(95 \% \mathrm{Cl})$ & $\begin{array}{c}\mathrm{p} \\
\text { value }\end{array}$ & $\begin{array}{l}R^{2} A \\
(\%)\end{array}$ & $\beta \mathrm{Aj}(95 \% \mathrm{Cl})$ & $\begin{array}{c}\mathrm{p} \\
\text { value }\end{array}$ & $\begin{array}{l}R^{2} A \\
(\%)\end{array}$ & $\beta \mathrm{Aj}(95 \% \mathrm{Cl})$ & $\begin{array}{c}\mathrm{p} \\
\text { value }\end{array}$ \\
\hline Socioeconomic status & & & & 17.5 & & & 17.5 & & \\
\hline Maternal schooling & 12.2 & $0.353(5.72 ; 10.45)$ & 0.000 & & $0.291(4.30 ; 9.04)$ & 0.000 & & 0.291 (4.30; 9.04) & 0.000 \\
\hline Family income & 9.8 & $0.317(4.47 ; 8.88)$ & 0.000 & & $0.243(2.94 ; 7.30)$ & 0.000 & & $0.243(2.94 ; 7.30)$ & 0.000 \\
\hline Environment & & & & 8.8 & & & 21.3 & & \\
\hline $\begin{array}{l}\text { Quality of internal } \\
\text { home environment }\end{array}$ & 4.9 & $0.228(2.65 ; 7.37)$ & 0.000 & & $0.175(1.45 ; 6.23)$ & 0.002 & & $0.119(0.36 ; 4.85)$ & 0.023 \\
\hline $\begin{array}{l}\text { Home density } \\
\text { (persons per room) }\end{array}$ & 6.2 & $-0.255(-2.58 ;-1.06)$ & 0.000 & & $-0.211(-2.28 ;-0.73)$ & 0.000 & & $-0.150(-1.80 ;-0.34)$ & 0.004 \\
\hline Proximal processes & & & & 18.7 & & & 27.5 & & \\
\hline $\begin{array}{l}\text { Provision of play } \\
\text { materials and } \\
\text { games to the child }\end{array}$ & 14.4 & $0.383(1.43 ; 2.47)$ & 0.000 & & $0.302(0.98 ; 2.09)$ & 0.000 & & $0.200(0.48 ; 1.56)$ & 0.000 \\
\hline $\begin{array}{l}\text { Maternal involvement } \\
\text { with the child }\end{array}$ & 5.6 & $0.242(0.98 ; 2.53)$ & 0.000 & & $0.095(-0.09 ;-1.47)$ & 0.084 & & & \\
\hline School attendance & 7.6 & $0.281(4.00 ; 8.86)$ & 0.000 & & $0.200(2.25 ; 6.23)$ & 0.000 & & $0.170(1.64 ; 6.16)$ & 0.001 \\
\hline Individual processes & & & & 5.0 & & & 28.0 & & \\
\hline $\begin{array}{l}\text { Nutritional status } \\
\text { (weight/age ratio) }\end{array}$ & 2.6 & $0.170(0.50 ; 2.37)$ & 0.003 & & $0.123(0.05 ; 2.00)$ & 0.041 & & $0.089(-0.07 ; 1.58)$ & 0.073 \\
\hline Birth order & 1.5 & $-0.136(-1.14 ;-0.12)$ & 0.015 & & $-0.152(-1.20 ;-0.19)$ & 0.007 & & & \\
\hline Birth weight & 2.3 & $0.162(0.001 ; 0.005)$ & 0.004 & & $0.107(0.000 ; 0.004)$ & 0.073 & & & \\
\hline
\end{tabular}

cance. On the other hand, nutritional status as to the indicator weight/age ratio had a moderate association ( $\beta=0.170$ ) with cognitive development scores in the univariate analysis, but when other variables were also included, the strength of association was lost $(\beta=0.089)$. Thus, this suggests that nutritional status has no effect on early cognitive development scores when the child is already poorly stimulated in an environment lacking appropriate play materials and educational resources.

\section{Discussion}

The results suggest that early cognitive development is multifactorial and is affected by the child's social environment, both proximal and distal. Among the aspects present in the proximal context, the existence of play materials and games (appropriate for the child's age) and attendance at preschool were the most important predictors of cognitive development. In general, play materials are used as mediators of proximal processes, primarily through adult-child interactions. These interactions facilitate mental processes responsible for cognitive development, such as discrimination, perception, and learning. As a result, the absence of stimulating materials can decrease the effectiveness of proximal processes and limit competency development 9,22,30.

The early insertion of a child in a preschool micro-environment can also be considered an important stimulator for early cognitive development. At school, the infant can be constantly challenged cognitively with stimuli that are rarely present in the home environment due to the scarcity of material and educational resources. Therefore, as the proximal processes in which the child is involved become more complex, competency development is enhanced 9 .

An interesting finding in the present study demonstrates that proximal processes are associated with external environmental factors such as family income and maternal education. In other words, socioeconomic factors indirectly affect children's early cognitive development by means of, in the proximal environment, the pro- 
vision of appropriate play materials and games and school attendance. The lower the maternal schooling and family income, the poorer the psychosocial stimulation, as children are deprived of play materials and school stimulation, negatively affecting their cognitive development.

The study findings corroborate those described in the literature, indicating that maternal schooling affects children cognitive development by means of environmental organization, parental expectations and practices, provision of materials for child's cognitive stimulation, and variety in daily stimulation 11,29,31,32,33,34. However, Bronfenbrenner \& Ceci 35 claim that socially disenfranchised families have neither adequate knowledge nor resources to provide a highly stimulating environment. This is especially significant since parents are regarded as largely responsible for their children's immediate environment, as they not only respond to their children's initiatives but also engage them in other activities involving interaction with people and contact with other objects, symbols, and stimuli.

However, it should be emphasized that even though evidence demonstrates that socioeconomic status is an important predictor for cognitive development, it is critical to consider that there is significant variability in childhood experiences at each social level. Each family reacts differently to resource deprivation, and one should consider the existence of social support nets, family dynamics, and child resources to overcome adversity 4,11,36.

Developmental aspects that were studied in this paper are not prognostic, i.e., the cognitive development of these children is mutifactorial and the final developmental result may be influenced by other events that occur in the macro or micro context, with a dynamic interaction between environmental factors and personal characteristics. It is possible that the predictor strengths and dynamics studied here would produce additional results when psychological and affective factors, which were not studied in this paper, are considered.

Poor quality of home environment stimulation can adversely affect children's development, leading to cognitive deficits 22,23 and subsequently to behavioral disorders 37,38 . However, one should bear in mind that the HOME inventory, although widely applied in a variety of cultural backgrounds, may not be perfectly suitable for measuring the quality of the environment of Brazilian children, especially those from low-income families. Also, as an external instrument, the HOME inventory may not be sensitive to specific forms of organization of the developmental environment in the population studied here.
Although there is evidence to support the idea that personal characteristics can influence the child's capacity to engage in proximal processes, and consequently, the child's development, this work demonstrates that individual health characteristics were not related to early cognitive development. No association was found between early cognitive development and nutritional status; there was a stronger impact of socioeconomic and psychosocial stimulation factors on the study findings. Malnutrition may not affect early cognitive development when the child is already integrated into a poor environment with inadequate economic and educational resources.

Several authors refer to the need to differentiate the effects of malnutrition from those related to the poor environment where malnourished children live 16,19. Lucas et al. 18 stress that malnourished children are from poor population groups with high child mortality and parents who are less equipped to care for and stimulate their children. Major improvements in child development have been evidenced in settings with adequate health, nutrition, and stimulation 39,40,41.

It should be emphasized that the present study included mostly well-nourished $(\geq-1$ $\mathrm{Z}$-scores) or low nutritional risk children $(-2 \leq$ $\mathrm{z}$-scores $\leq-1)$ and that the proportion of children with moderate malnutrition $(-3 \leq \mathrm{z}$-scores $\leq-2)$ was low and none had severe malnutrition ( $\leq-3$ z-scores). Meanwhile, most studies showing a relationship between malnutrition and cognitive development included severely malnourished children where the effects of malnutrition on children's cognitive development were even more damaging $6,18,19,41$.

The study analysis strategy was conceived to be both theoretically relevant and technically innovative. Although cross-sectional designs are not considered a consistent approach for demonstrating causality, they allow exploring a large set of variables from multiple domains while assessing the impact of socioeconomic status, environment, family, parental styles and practices, and child health status on children's cognitive development. Explanatory variables were hierarchically arranged and included in the model following theoretical criteria, thus preventing relevant variables from being excluded from the analysis based on statistical criteria, which are sometimes arbitrary.

The present study goes further than other studies on childhood cognitive development conducted in Brazil, which have mainly focused on describing risk factors and prognosis of low birth weight and prematurity 24,25,26. Nutritional studies in Brazil have focused on biological and social determinants (both proximal and distal) of 
children's nutritional status 5,12,42,43 without attempting to explore any associations with their cognitive development.

Poor social and cognitive stimulation in the home environment has long-term effects as well, as concluded by Bastos \& Almeida-Filho ${ }^{38}$, remarking that deficits resulting from a poor environment in the early years of life have lifetime implications. Cognitive deficits, in conjunction with a poor home environment, can act as mech- anisms of social exclusion as they further limit these children's learning opportunities. Allied to health actions to fight malnutrition, there is a need to provide children with better quality of life through actions promoting early stimulation, as well as implementing preschools and early intervention programs to provide mothers with the required resources for their children's healthy growth and development.

\section{Resumo}

Trata-se de um estudo longitudinal sobre a relação entre estado antropométrico, condições sócio-econômicas, qualidade do ambiente doméstico e desenvolvimento cognitivo de 320 crianças de 20 a 42 meses de idade, selecionadas através de amostragem aleatória estratificada em um conjunto de 20 mil residências de diferentes níveis econômicos e condições ambientais em Salvador, Bahia, Brasil. O critério de inclusão foi ter menos de 42 meses entre janeiro e julho de 1999. O desenvolvimento cognitivo foi avaliado pela escala Bayley de desenvolvimento infantil, e o inventário HOME de observação doméstica avaliou a qualidade do ambiente doméstico. Os indicadores peso/idade e altura/idade (escores-z) identificaram o estado antropométrico, e as informações sócio-econômicas foram obtidas utilizando-se questionário padronizado. Utilizou-se a técnica da regressão linear univariada e regressão linear hierarquizada para as análises estatísticas. Encontrou-se que os fatores sócio-econômicos influenciam o curso do desenvolvimento cognitivo na primeira infância de maneira indireta, sendo mediados por fatores do contexto proximal da criança, como disponibilidade de materiais e jogos adequados $e$ freqüência escolar. Não se encontrou uma associação independente entre estado nutricional infantil e desenvolvimento cognitivo na primeira infância.

Desenvolvimento Infantil; Pré-Escolar; Estado Nutricional

\section{Contributors}

L. M. Santos contributed with data collection, instrument adaptation, data analysis, and interpretation, as well as writing the first draft of the article. D. N. Santos was involved in the study planning and design, data analysis and interpretation, and review of the manuscript draft. A. C. S. Bastos provided advice on the application of psychological instruments, data analysis and interpretation, and review of the draft. A. M. O. Assis was involved in the study planning and design, data analysis and interpretation, and review of the draft. M. S. Prado coordinated data collection in the early cohort, conducted nutritional data analysis and interpretation, and reviewed the draft. M. L. Barreto, principal investigator of the main study from which this present study was derived, was involved in the study planning and design, data interpretation, and review of the draft. 


\section{References}

1. Flavell JH, Miller PA, Miller SA. Desenvolvimento cognitivo. Porto Alegre: Editora Artmed; 1999.

2. Berkman DS, Lescano AG, Gilman RH, Lopez SL, Black MM. Effects of stunting, diarrhoeal disease, and parasitic infection during infancy on cognition in late childhood: a follow-up study. Lancet 2002; 359:564-71.

3. Johnson MH. Development neuroscience. In: Bornstein MH, Lamb ME, editors. Developmental psychology: an advanced textbook. Mahwah: Lawrence Erlbaum Associates; 1999. p. 199-230.

4. Oliveira EA. Modelo de risco na psicologia do desenvolvimento. Psicol Teor Pesqui 1998; 14:19-26.

5. Carvalhaes MA, Benício MH. Capacidade materna de cuidar e desnutrição infantil. Rev Saúde Pública 2002; 36:188-97.

6. Connolly KJ, Kvalsvig JD. Infection, nutrition and cognitive performance in childhood. Parasitol 1993; 107:187-200

7. Costa-Junior A, Zanon CM. Desnutrição e desenvolvimento comportamental: questões metodológicas. Estud Psicol (Natal) 1997; 2:263-76.

8. Tizard J. Early malnutrition, growth and mental development in man. Br Med Bull 1974; 30:169-74.

9. Bronfenbrenner U, Morris PA. The ecology of developmental process. In: Gomes-Pedro J, editor. Stress and violence in childhood and youth. Lisboa: Universidade de Lisboa; 1999. p. 21-95.

10. Campino ACC. Aspectos sócio-econômicos da desnutrição no Brasil. Rev Saúde Pública 1986; 20:83-101.

11. Bradley R, Corwyn R. Socioeconomic status and child development. Annu Rev Psychol 2002; 53:371-99.

12. Olinto MTA, Victora CG, Barros FC, Tomasi E. Determinantes da desnutrição infantil em uma população de baixa renda: um modelo de análise hierarquizado. Cad Saúde Pública 1993; 9 Suppl 1: S14-27.

13. Monteiro C, Benício MH, Freitas IC. Melhoria dos indicadores de saúde associados à pobreza no Brasil nos anos 90. São Paulo: Núcleo de Pesquisas Epidemiológicas em Nutrição e Saúde, Universidade de São Paulo; 1997.

14. Drewett R, Wolke D, Asefa M, Kaba M, Tessema F. Malnutrition and mental development: is there a sensitive period? A nested case-control study. J Child Psychol Psychiatry 2001; 42:181-7.

15. Gordon N. Nutrition and cognitive function. Brain Dev 1997; 19:165-70.

16. Gorman KS. Malnutrition and cognitive development: evidence from experimental/quasi-experimental studies among the mild-to-moderately malnourished. J Nutr 1995; 125(8 Suppl): 2239S$44 \mathrm{~S}$

17. Lucas A. Programming by early nutrition: an experimental approach. J Nut 1998; 125(2 Suppl): 401S-6S.

18. Lucas A, Morley R, Isaacs E. Nutrition and mental development. Nutr Rev 2001; 59(8 Pt 2):S24-32.
19. Mendez MA, Adair LS. Severity and timing of stunting in the first two years of life affect performance on cognitive tests in late childhood. J Nutr 1999; 129:1555-62.

20. Strina A, Cairncross S, Barreto ML, Larrea C, Prado MS. Childhood diarrhea and observed hygiene behavior in Salvador, Brazil. Am J Epidemiol 2003; 157:1032-8.

21. Bayley N. The Bayley Scales of Infant Development: second edition. San Antonio: Psychological Corporation; 1993.

22. Andraca I, Pino P, Parra A, Rivera F, Castillo M. Factores de riesgo para el desarrollo psicomotor en lactantes nacidos en óptimas condiciones biológicas. Rev Saúde Pública 1998; 32:138-47.

23. Laude M. Assessment of nutritional status, cognitive development, and mother-child interaction in Central American refugee children. Rev Panam Salud Pública 1999; 6:164-71.

24. Bordin MBM, Linhares MBM, Jorge SM. Aspectos cognitivos e comportamentais na média meninice de crianças nascidas pré-termo e com muito baixo peso. Psicol Teor Pesqui 2001; 17:49-57.

25. Eickmann SH, Lira PI, Lima M. Desenvolvimento mental e motor aos 24 meses de crianças nascidas a termo com baixo peso. Arq Neuropsiquiatr 2002; 60:748-54

26. Meio MDBB, Lopes CS, Morsch DS. Fatores prognósticos para o desenvolvimento cognitivo de prematuros de muito baixo peso. Rev Saúde Pública 2003; 37:311-8.

27. Caldwell B, Bradley RH. Home Observation for Measurement of the Environment (HOME): revised edition. Little Rock: University of Arkansas Press; 1984.

28. Organización Mundial de la Salud. Medición del cambio del estado nutricional: directrices para evaluar el efecto nutricional de programas de alimentación suplementaria destinados a grupos vulnerables. Genebra: Organización Mundial de la Salud; 1983.

29. Zamberlan MAT, Biasoli-Alves ZMM. Detecção de níveis de riscos psicossociais através do inventário HOME em ambientes de populações urbanas de baixa renda. In: Zamberlan MAT, Biasoli-Alves ZMM, organizadores. Interações familiares: teoria, pesquisa e subsídios à intervenção. Londrina: Universidade Estadual de Lonrina; 1997. p. 143-61.

30. Shaffer D. Psicologia do desenvolvimento: infância e adolescência. São Paulo: Pioneira Thomson Learning; 2005

31. Andrade AS, Santos DN, Bastos AC, Pedromônico MR, Almeida-Filho N, Barreto ML. Ambiente familiar e desenvolvimento cognitivo infantil: uma abordagem epidemiológica. Rev Saúde Pública 2005; 39:606-11.

32. Hutz CS, Koller SH, Bandeira DR. Resiliência e vulnerabilidade em crianças em situação de risco. Coletâneas da ANPEPP 1996; 1:79-87. 
33. Reed BA, Habicht J, Niameogo C. The effects of maternal education on child nutritional status depend on socio-environmental conditions. Int J Epidemiol 1996; 25:585-92.

34. Zamberlan MAT, Biasoli-Alves ZMM. Ambientes domiciliares de famílias de baixa renda de área urbana. In: Zamberlan MAT, Biasoli-Alves ZMM, organizadores. Interações familiares: teoria, pesquisa e subsídios à intervenção. Londrina: Universidade Estadual de Lonrina; 1997. p. 109-41.

35. Bronfenbrenner U, Ceci SJ. Nature-nurture reconceptualized in developmental perspective: a bioecological model. Psychol Rev 1994; 101:568-86.

36. Sapienza G, Pedromônico MRM. Risco, proteção e resiliência no desenvolvimento da criança e do adolescente. Estud Psicol (Natal) 2005; 10:209-16.

37. Bradley R, Corwyn R, Mcadoo H, Coll C. The home environments of children in the United States part I: variations by age, ethnicity, and poverty status. Child Dev 2001; 72:1844-67.

38. Bastos ACB, Almeida-Filho N. Variables socio-económicas, ambiente familiar y salud mental. Acta Psiquiátr Psicol Am Lat 1990; 36:127-54.
39. Grantham-McGregor S. A review of studies of the effect of severe malnutrition on mental development. J Nutr 1995; 125(8 Suppl):2233S-8S.

40. Kretchmer N, Beard JL, Carlson S. The role of nutrition in the development of normal cognition. Am J Clin Nutr 1996; 63:997S-1001S.

41. Pollitt E. A developmental view of the undernourished child: background and purpose of the study in Pangalengan, Indonesia. Eur J Clin Nutr 2000; 54 Suppl 2:S2-10.

42. Ferrari AA, Solymos GMB, Castillo RM, Sigulem DM. Risk factors for protein-energy malnutrition in pre-school shantytown children in São Paulo, Brazil. Rev Paul Med 1998; 116:1654-60.

43. Rissin A, Costa MJC, Batista-Filho M. Estado de nutrição de crianças nordestinas no advento dos anos 90: associação com algumas variáveis biológicas. Rev IMIP 1998; 12:3-7.

Submitted on 04/May/2006

Final version resubmitted on 21/May/2007 Approved on 23/May/2007 